\title{
模擬体験用航海シミュレーションおよび シーナビのシステムに対する評価について
}

\author{
柳 馨竹 1 ・塩谷 茂明 2 - 笹 健児 3 \\ 1 神戸大学大学院海事科学研究科（干 658-0022 神戸市東灘区深江南町 5-1-1） \\ E-mail: 118w316w@stu.kobe-u.ac.jp \\ 2 正会員 神戸大学教授 自然科学系先端融合研究環（干658-0022 神戸市東灘区深江南町 5-1-1） \\ E-mail: shiotani@maritime.kobe-u.ac.jp \\ 3 正会員 神戸大学准教授 神戸大学大学院海事科学研究科（干 658-0022 神戸市東灘区深江南町 5-1-1） \\ E-mail: sasa@maritime.kobe-u.ac.jp
}

\begin{abstract}
安全航海を目的に，著者らは出港前にこれから航海する航路の模擬体験航海を行い，航路の周辺状況の 把握が可能な航海シミュレーションシステムの基礎を構築した。 航たた，三次元海図を作成し，様々な航海 情報を重ね合わせて提供するシーナビのシステムの基礎部分を構築した。 これらのシステムにより，航路 状況の把握が容易となり，操船支援装置として有効であることが期待できる.

本研究の目的は，これら二種類のシステムの紹介と評価を行い，今後のシステムの高度化および改良を 図ることである。システムの評価は実習生に対しアンケート形式で実施した。 その結果，本システムが有 効であることがわかり，様々な意見から，これらのシステムの今後の発展に処することが可能になった．
\end{abstract}

Key Words : navigation support, navigation simulation, sea navigation, questionnaire times, GIS

\section{1. はじめに}

東京湾, 伊勢湾, および瀬戸内海などの閉鎖海域には, 船舶の輻軼度が高く, 複雑な地形と狭险な海域, さらに 船舶が互いに交差する危険な海域がある．このような海 域を, 経験が浅く, 初めて航海する航海士にとって, 緊 張感が増しパニック状態となり, 状況次第では判断を誤 り，海難誘発の恐れがある. 海上保安庁による事故原因 の分析結果によると, 操船者によるヒューマンエラーが 海難発生の主要原因である ${ }^{1)}$. 通常, 航海士は安全航海 のため, 様々な航海情報を収集した上で状況判断し, 操 船を行う。しかし，このような危険海域の航海では，多 様な状況を即座に判断することが要求される. その結果, 緊迫状態が続き, 判断を誤り, 海難の発生が危惧される.

著者らはこれらの状況を軽減し, 航海の安全性の向上 を目的に，操船支援システム構築の研究を行ってきた. 本研究の目的は, 二種類のシステムの基礎を構築したの で，それらの概要を紹介し，システムの有效性をアンケ ート調査によって評価した。第一番目は, 出港の事前に これから航海する航路の模擬航海ができる模擬体験用航 海シミュレーションである. 第二番目は, 航海中に詳細 な航海支援情報が得られる, 道路交通でのカーナビの海 バージョンのシーナビである. システムの評価を, 学生
を対象に実施した結果，システムの有效性が高いことが わかった。 さらに，今後システムの高度化および改良を 図るための有益な意見も得ることができた.

\section{2. 操船支援システムの概要}

\section{（1） 模擬体験用航海シミュレーション}

出港の事前に航路を模擬体験航海ができるシステム は, 特に, 経験が浅く, 初めての海域を航海する航海士 にとって，周辺海域の把握を可能にする，その結果，実 航海では緊張感が和らぐことが期待できる.

航海シミュレーションは最初に船橋から見える景色 を PC のモニターに三次元表示した. 地形は GIS（地理 情報システム）で製作した. 神戸大学大学院海事科学研 究科附属練習船「深江丸」による, 高松港までの航路を 再現した．船橋から見える景色は動画で再現した ${ }^{22}$.

同様の装置に，操船シミュレータがある．これは操船 訓練が主目的であり, 大掛かりな装置と広い建屋が必要 である ${ }^{3)}$. しかも, 数億円の経費と高度の管理運営を有 する. しかし, 本システムの特徴は, ノート型パソコン を用い，安価で携帯可能である. ユビキタス（いらでも どこでも）な利用と，初心者も容易に使用できる. 
最初に，三次元地形図に，船上では見えない海底地形 を表示した．これは船舶乗り揚げ防止が目的である。さ らに数值計算による船舶周りの気象・海象（海上風，潮 流および波浪分布）を表示した。これにより航行船舶へ の気象・海象の影響の予測が可能になる ${ }^{4}$.

次に，航路標識や物標などの設置場所をクリックする と，三次元立体航路標識や詳細な解説が表示できる.こ れは主要物標の確認と詳細情報を提供する.さらに, 他 船の動向を考慮し，横切り船および反航船を表示した. これは狭水道での他船との危険な関係の把握である。

\section{(2) シ一ナビゲーションの概要}

道路交通のカーナビは，二次元地図の他，道路に面し た建物などを立体的に提供するので，走行周辺地域の確 認・イメージが容易である. カーナビを小型船舶に搭載 し，その有効性を評価した ${ }^{5)}$. 供試船は海事科学研究科 附属実習船「むこ丸」で, 深江周辺の沿岸域を航行した. その結果，小型船舶にカーナビが有効な航海情報を提供 することがわかった．そこで，シーナビの基礎部分を構 築した ${ }^{6}$. ノート型 PC に船首前方を撮影用のビデオカメ ラと GPS を接続した. PC のモニターに三次元および二 次元海図, ビデオカメラ映像および GPS の航海情報 (時 刻，船位，船速等）を表示した。二，三次元海図と GPS を組み合わせ, リアルタイムに海図上で船位が移動する。

道路上では，夜間でも，ヘッドライト，街灯，ビルの 照明などにより，道路周辺は比較的明るい。しかし，海 上では夜間の船舶周辺海域は真つ暗闇であり，初心者に とって，海域の把握が非常に困難な場合がある. もし， 昼間の景色が再現できると，状況判断が容易となり，操 船支援装置として利用できる，逆に，日中の航海中に， 夜間および薄暮時の状況を再現し，夜航海のイメージ造 りも可能である．夜間の航海支援システムになる.

また，プレジャーボート等の操船者は休日のみの乗挺 が多い，専業の航海士でなく，操船技術が未熟な場合が 多い. 特に入出航時では対岸や航路標識などの距離感が 不安定である．これを解消するために，自船から一定距 離間隔の環を表示することで，距離感覚が改良された。

\section{3. システムの評価}

アンケートによるシステム評価を実施した．被験者は， 海事科学部航海課程の3年生 45 名である。学生は3ケ月の 乗船履歴と, 操船技術を習得している. アンケートは最 初にシステムの目的と概要を説明した. 次に, システム を要素毎に分離して，プロジェクターで表示し，5段階表 示で評価をアンケート用紙に記入する. 5段階評価は (5： 優れている. 4 : ある程度評価できる. 3 : 普通である. 2 :
あまり評価できない. 1 : 全く評価できない. ) である. 同時に，自由に意見が記入できるようにした.

\section{(1) 模擬体験用航海シミュレーション}

図-1に三次元航路標識を示す。三次元海困中の航路標 識の記号をクリックすると，製作した三次元航路標識お よび詳細な解説や写真などが表示できる.これにより， 主要な航路標識の詳細な確認が可能である.

図-2にアンケート結果を示寸.評価5は0\%であるが， 4, 3 の合計が $89 \%$ と高い評価を得た．主な意見は，以下 の通りである．1)動画より静止画のほうが見易い．2)文 字を大きくして灯質と名称を見易くするとよい. 3)航路 標識は重要情報のため，確認できると安心感が違う。

図-3 に詳細な水深情報を示す. 水深は三次元海底地形

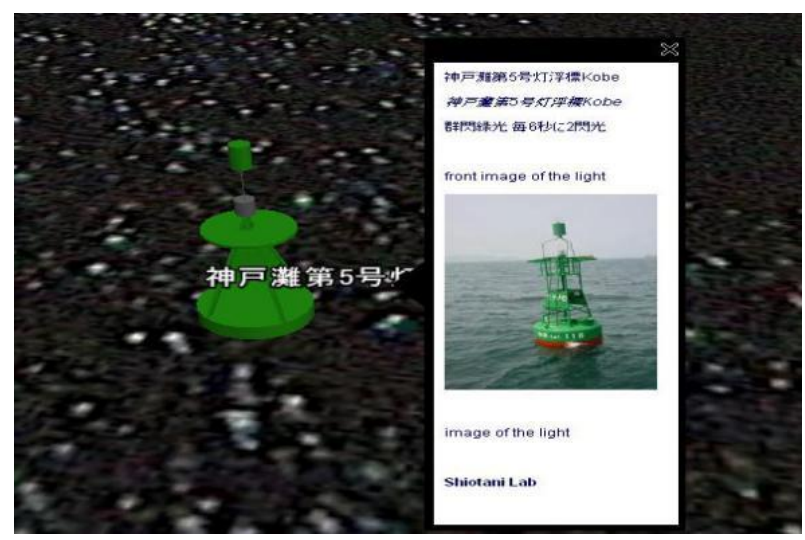

図-1 三次元航路標識と解説 ${ }^{6}$

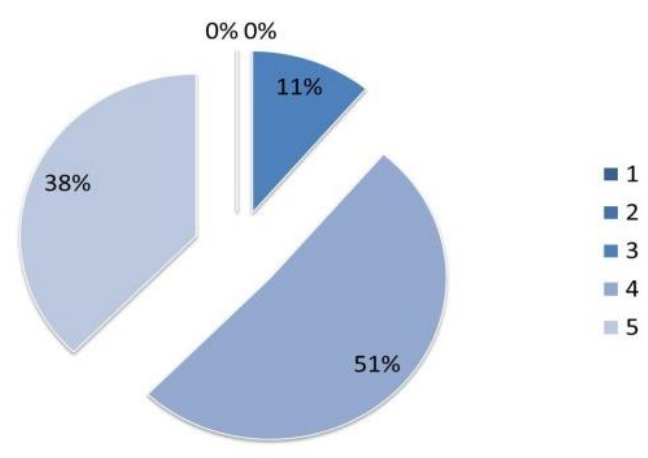

図-2＼cjkstart航路標識のアンケート結果

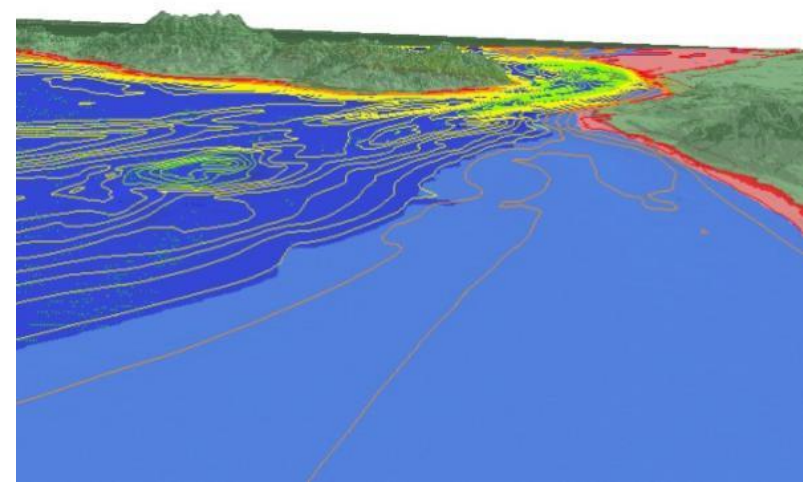

図-3 航路周辺海域の水深情報 
および任意間隔の等水深線などで表示した，また，水深 により海面の色を変えた(濃い青色が深い).ささらに, 自 船の喫水より浅い海域を座礁の危険性のある海域として 赤色で表示した. 自船がその海域に進入すると警告（文 字や音）を発するシステムも可能である.

図-4にアンケート結果を示す.評価5 は0\%であるが, 4, 3 の合計が $86 \%$ と比較的高い評価を得た. 主な意見は 以下の通りである. 三次元地形に可能ならば地名を記入 すると, より優れた映像になる. 2)非常に画期的であり， 直感的判断に役立つ. 3)数字のみで書かれている海図よ りも見易くてよいと思う。4)縮尺が分かり難い，距離感 がつかみ難い. 5)ある程度の建造物を示すと解りや寸い. 6)3 次元海底地形が見にくかった.

図-5に全海域の気象・海象（潮流の流向流速，海上風 の風向風速，波浪の波向波高分布）の情報を示す. 気象・ 海象のデータは数值計算で得られた予測值であるので, 船体周辺海域における時空間的変化の表示も可能である.

図-6に気象・海象情報についてのアンケート調査結果 を示す．評価 5 が 40\%，4 が 40\%，3 が 16\% と非常に高 い評価を得た. 現状の気象・海象の情報はFAX, 風向風 速計および電磁ログなどから得るが，リアルタイムの表 示はない. 主な意見は以下の通りである. 1)べクトル表 示だけでなく，流れ（風速，潮流の流速）に合わせて流 速ベクトルも一緒に動かすと良いかもしれない，2)流れ の速さを数值で表示して，動画を見た時に，たまに分か ったほうが良い．3)波高が見難くい．波高は海面の色別 で表示しているので, 数值が不明であることは今後の改 善点であると思われる.4) 一目で流向や風向風速が分り， 自船がどのような影響を受けているか分かる. 5) 視覚的 にもっと単純なもののほうがいいかもしれない.6) 天気 図で見るのと違い, イメージが付きやすく, 潮流と風の

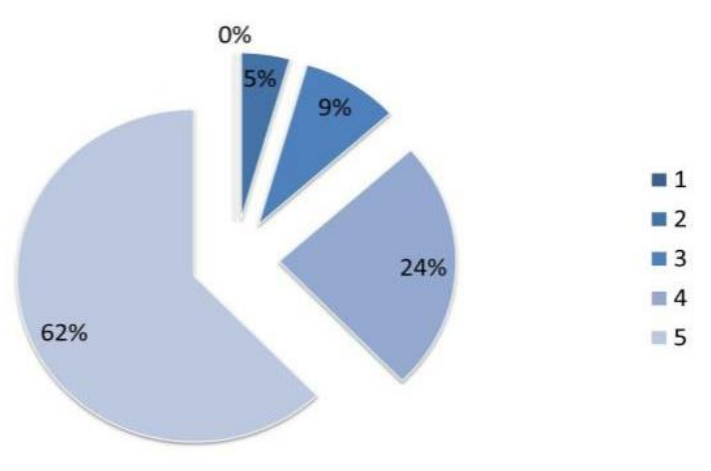

図-4＼cjkstart水深情報のアンケート結果

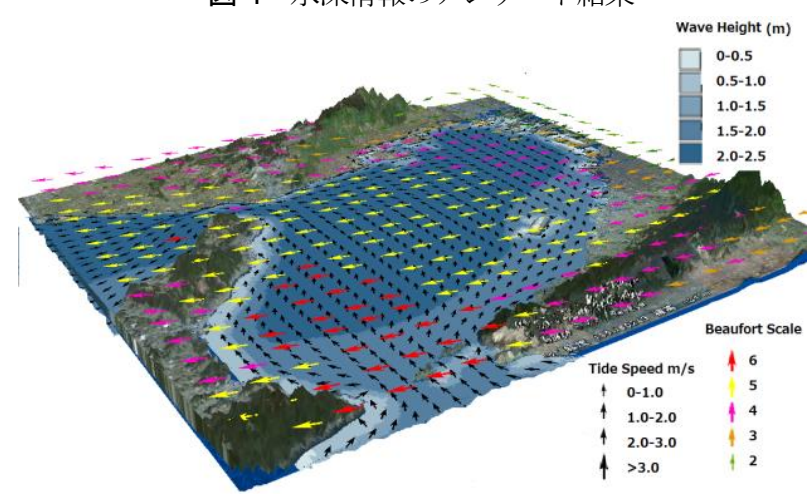

図-5＼cjkstart湾内の気象・海象情報 ${ }^{4)}$

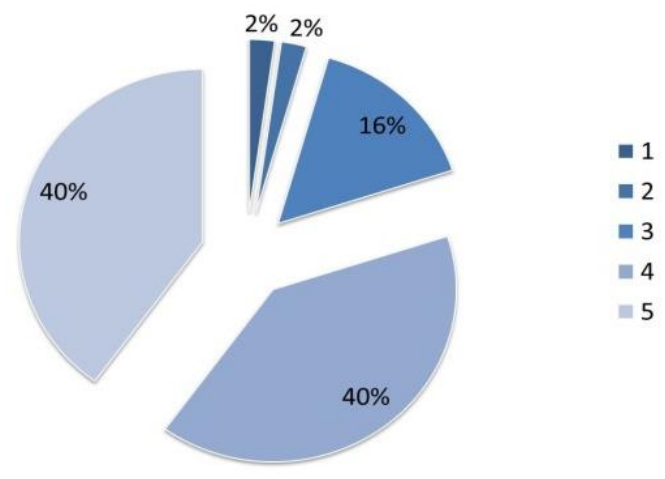

図-6 気象・海象情報のアンケート結果

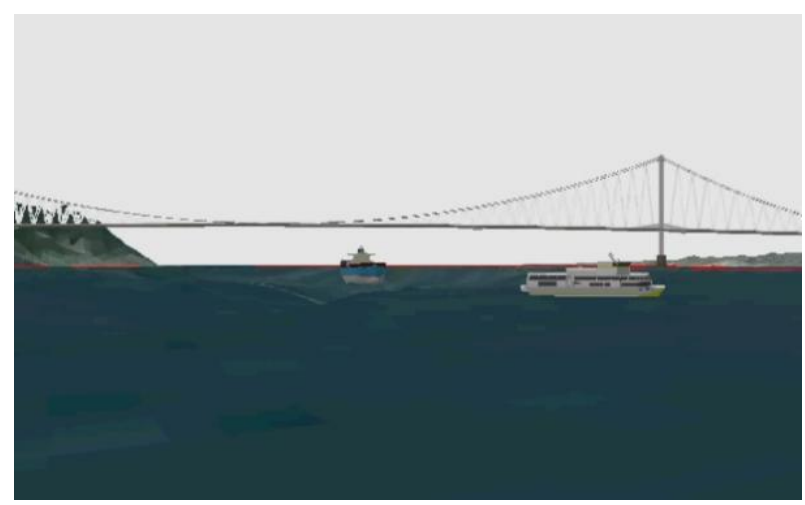

図-7 他船動向の情報

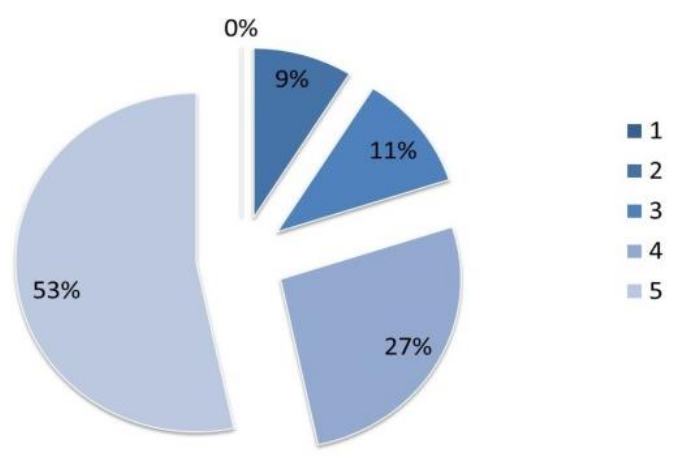

図-8＼cjkstart他船動向の情報のアンケート結果

情報を同時に確認出来るのは良いと思った.

図-7に船舶の輻輳度が高い狭水道等において, 他船の 動向も考慮して，模擬船舶の航行を示す. 船首前方の横 切り船および反航船を三次元で制作し，他船との危険な 状況をイメージさせた．海域は狭水道である明石海峡周 辺である.

図-8に他船動向の情報のアンケート結果を示す. 評価 5 が 53\%，4 が 27\%，3 が $11 \%$ と高い評価を得た。意見 は以下の通りである．1)上から見た画面（鳥瞰図）も見 たい，操船シミュレータとの違いが分からない，2)レー ダーで実際の船舶を用いたシミュレーションはあるが, こういらたシミュレーターはより優れていて，便利かも しれない. 3)レーダーであるとどのように見えるのか, また他船との距離が分らないので, 物標との距離や針路, 


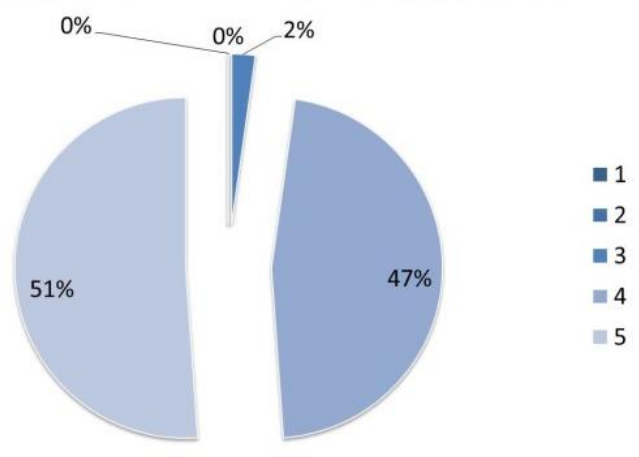

図-9

シミュレーションの総合評価のアンケート結果

速度の分かるものも付けてほしい，4)航路上の法規が一 緒に確認できたらよい.

図-9 に模擬体験航海用シミュレーションの総合評価 の結果を示す. 総合評価 5 が $51 \%, 4$ が $47 \%$ ， 3 が $2 \%$ と 非常に高い評価を得た．主な意見は以下の通りである. 1)付加すればよい情報として, 経験, 船長協会の推奨航 路, 航行の際の判断材料などがある. 2)大まかな概要, 傾向を知る上では，リアル感があってよかった．3)安価 で持ち運びできるのはとても良いと思う。4)もう少しリ アリティのある映像になれば，より多くの人に効果があ ると思う。

(2)

一般に操船者は紙媒体の海図や電子海図(ECDIS)を用 いて航海する. しかし，プレジャーボート等の多くの操 船者は職業として操船しないので，経験未熟であり，二 次元海図を使いこなすまでに相当の経験を要する. 人間 は三次元の世界に生きているので，カーナビのように， 現実の景色が三次元立体地形で見える三次元海図の方が, 理解度が高くなる場合がある。このような目的で，カー ナビに対応したシーナビシステムの基礎を構築した.

図-10 に PC 画面に表示されたシーナビを示す. 図中 の左下に船上から見える三次元海図を示寸．図中の橋は 神戸市内と六甲アイランドを繋ぐ六甲大橋であり，別途 製作後に三次元海図に貼り付けた. 三次元海図は立体感 があり，現実的な海図を提供する.

図-11 に三次元海図についてのアンケート調査結果を 示す. 評価 5 が 40\%，4 が 40\%，3 が 18\% と非常に高い 評価を得た. 主な意見は以下の通りである. 1)車と同様, GPS の精度の問題があると思う．2）情報が多寸ぎて必要 な情報がどれか見失いそうな気がする．3）予定航路を表 示してほしい，4)分かりやすくなり, 周囲の状況が格段 に把握しやすくなるので，素晴らしいと思う．5)実際に 船舶に配備されて欲しい，図-10 の右上に二次元海図を 示す．図中に船位を記号で示す，船速に従って移動する
土木学会論文集B3 (海洋開発), Vol. 71, No. 2, I_197-I_202, 2015.

ので，電子海図(ECDIS) と同等の作用をする.

図-12 に二次元海図についてのアンケート調査結果を 示す. 評価 5 が 47\%，4 が 33\%，3 が 20\% と非常に高い 評価を得た．主な意見は以下の通りである．1）2 次元海 図は ECDIS のみで良い気がする．2) 海図と対応してい るのは良いと思う. 3) 慣れていることもあり，こちらの ほうが使いやすそう。4) 船の航跡があると一層良い.

図-10 の右下に船首前方の景色を撮影したビデオ映像 を表示す．薄暮時では，カメラの性能が優れ，目視より 景色が鮮明であり，船首前方がよく見える長所もある. 現在は船首前方の映像のみであるが, 今後, 両舷方向お よび後方の映像の表示もカメラの増設により，同時に可 能である.

図-13 にビデオ映像画像についてのアンケート調査結 果を示す. 評価 5 が $45 \%$ ，4 が $42 \% ， 3$ が $11 \%$ と高い評

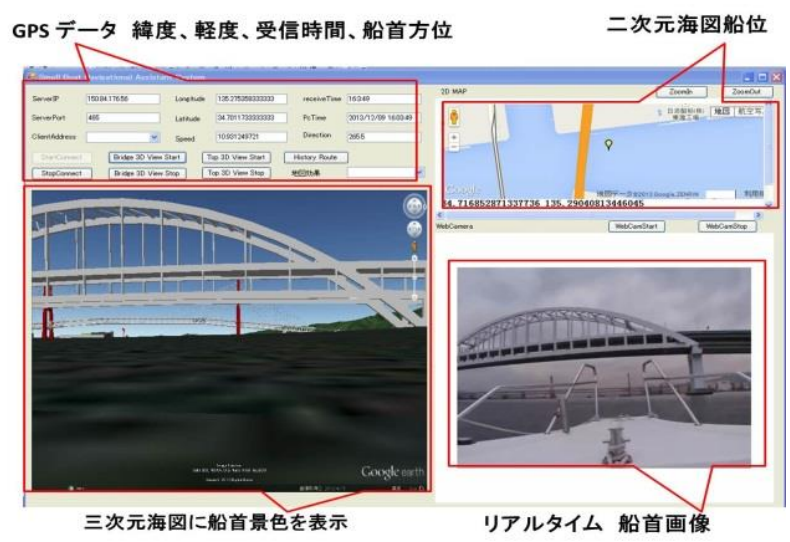

図-10 シーナビの表示

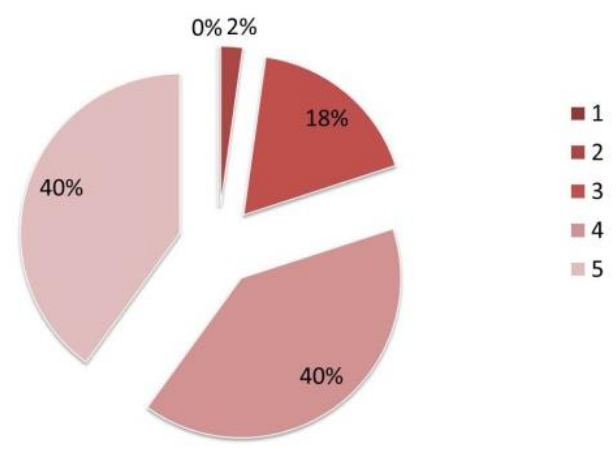

図-11 三次元海図のアンケート結果

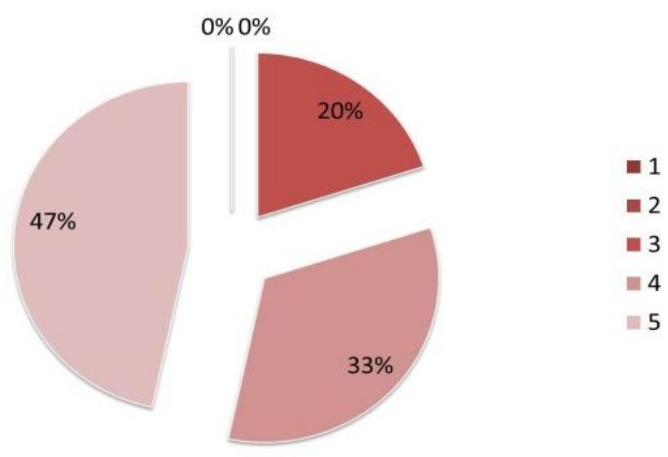

図-12 二次元海図のアンケート結果 

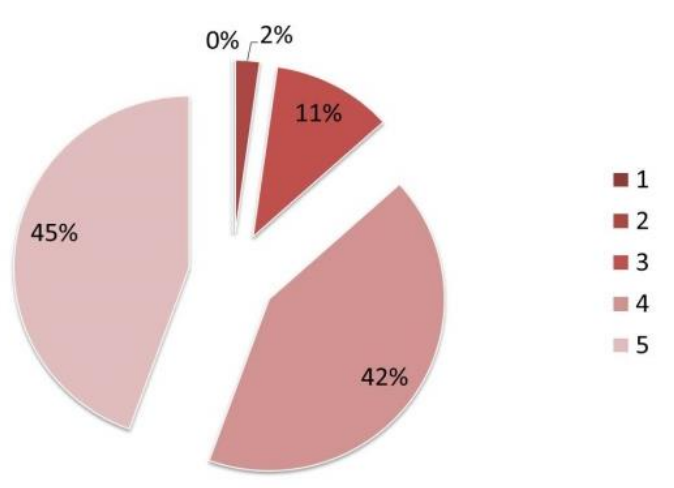

図-13 ビデオ映像のアンケート結果

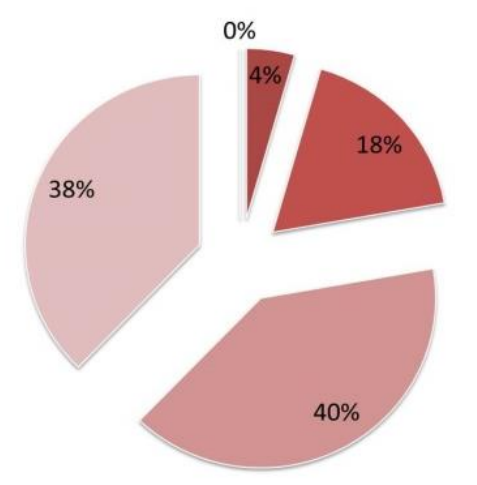

図-14 基本的な航海情報のアンケート結果

価を得た．主な意見は以下の通りである．1)全方位撮影 の対応であれば効果的である. 2)周囲の景色を理解する のに有益であると思う．3)夜間でも船が分かるようにな るのは非常に良いと思う．4)前方の状況は操縦席で得ら れるので不要な表示だと思う。この意見に対し, 操繸席 から, 正横方向および後方の状況をビデオカメラの増設 により, 確認出来ることも今後可能になると考えられる.

図-10の左上に GPS から得られた基本的な航海情報の 時間, 船位 (緯度, 経度), 船速, 船首方位などをリアル タイムに数值で表示している. これらの情報により航行 船舶の状況の把握が可能である.

図-14 に基本的な航海情報についてのアンケート調査 結果を示寸．評価 5 が 38\%，4 が 40\%，3が 18\%と高い 評価を得た. 主な意見は以下の通りである. 1) 航海士 にとって必要な情報なので良いと思う。2)必要なものだ けを選択して表示できればよい。この意見に対し, 各要 素を精査し，表示寸る工夫はできると考えている.

図-15に，本システムの夜間入港時の状況を示す．通 常では船体周辺海域は真っ暗闇であるため, 船舶周辺の 状況把握が十分でなく危険である. 図のように状況次第 で船舶の航行を上空から見る鳥瞰図で示すことにより， 夜間見えない岸壁や港入口の景色などがよく理解できる. また，一定間隔の距離環の描画により，港入口及び港内 付近の岸壁, 栈橋, 物標までの距離などの把握が容易で ある. 夜間でもビデオカメラは肉眼よりも前方の景色が 比較的鮮明であるので, 効果的である. また, 夜間時に,

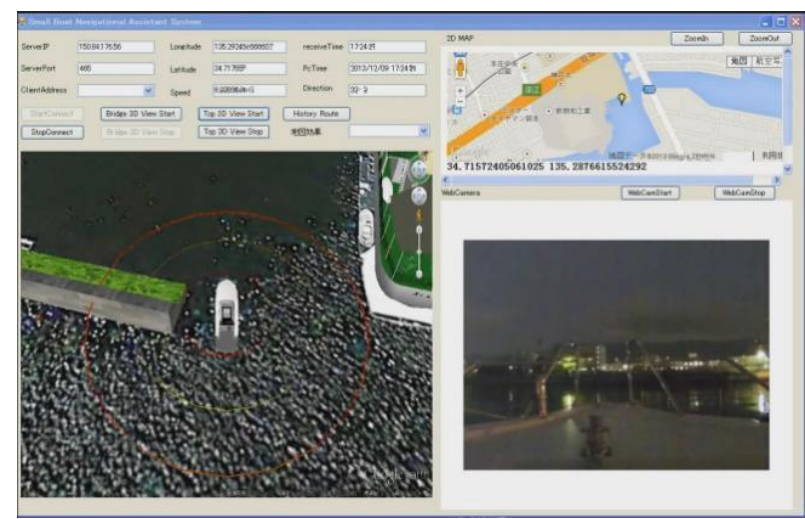

図-15 夜間入出港時のシーナビ ${ }^{6}$

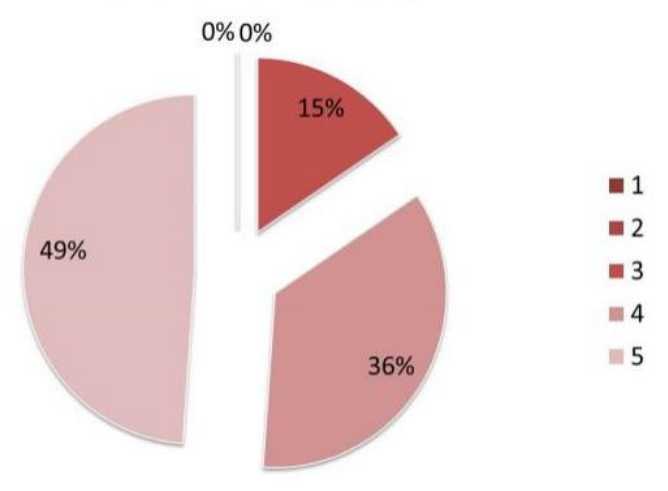

図-16＼cjkstart夜間シーナビのアンケート結果

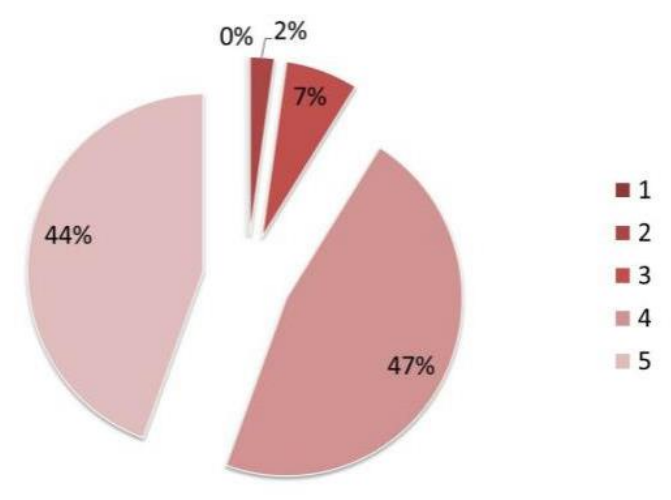

図-17 シーナビの総合評価のアンケート結果

昼間の景色を示すことも可能であり, 周辺海域の把握も 可能である.

図-16に，夜間におけるシーナビのアンケート調査結 果を示寸．評価 5 が 49\%，4 が 36\%，3 が 15\% と高い評 価を得た．主な意見は以下の通りである．11夜間は視覚 による情報が全く得られないため，このシステムがあれ ば安全な入港作業を行うことが出来る. 2) ビデオ映像は 見える範囲が決まっているので，もし船舶がたくさん航 行する海域は少し不安があると思った. 3) 肉眼よりも景 色が鮮明であるなら，良いツールだと思う。ただ，入港 は秒単位で物事が進んでいくので，コンピュータの動作 の遅れがない状態でないと実用的ではないと思う.4)こ れに頼り切って操船する人が出てくるのではないかと考 えると不安である. 5) 夜間操船の補助となるのは非常に 
有効的なものであると思う。

図-17 にシーナビシステムに対する総合評価のアンケ 一ト調査結果を示す. 評価 5 が 44\%，4 が 47\%，3 が $7 \%$ と非常に高い評価で，余り評価できないは僅かに $2 \%$ 過ぎない. 主要な意見は以下の通りである.1) 初心者お よび少し知識のある者に対し. 使い分けて用いると非常 に有効なシステムであると考える. 2) 1 度でも見たこと があるというのは，航海において大きなアドバンテージ となるので, 有益と思った. 3) 三次元海図に自船および 他船の針路，船速，コースラインなどが書かれ，交差す るのか, どこで危険かを示せるようになれば良いと思う。

\section{(3) 評価の低い項目}

各項目に対する意見はほとんどが希望事項や軽微な改 善点であり，評価できない項目は少なかった。主な項目 を列挙すると以下の通りである.

1)模擬体験用航海シミュレーション

a)動きがカクカクして見にくい. b)画面に映す情報量 が多くなると分かり難い. c)距離感がつか夕難い. ある 程度建造物が有る方が理解し易い. d)このシステムで, 自分の意志で操船できれば利用度が一層高まる.

2)シーナビゲーション

a)見張りとして外の景色を常時見るので，パソコンを 見ていると逆に，事故が起こりやすくなる．b)車と同様 に，GPS の精度に問題があると思う。c)入出港時は秒単 位で物事が進むので, PC の動作遅れがない状態でないと 実用的でない. d)経験の浅い人が操船する場合，シーナ ビ頼りの操船になると，別の危険が出ると思う。

これらの意見は，重要であり，今後改良点として，シ ステムに取り組んでいきたい。

\section{4. 結論}

模擬体験用航海シミュレーションおよびシーナビの
システムの基礎部分を構築し，これらシステムの概略を 示しアンケートによる評価を行った．その結果，両シス テムの評価は非常に高かった。 また，システムに対する 多数の意見を得た。これらの貴重な意見から，航海士に 有効な情報提供が可能なシステムの改善点および高度化 の指針が多数得られた. 今後これらの有益な指摘事項に 基づいた研究の発展が可能となった．特に，プレジャー ボートなどはレーダー, ECDIS 等の高価な航海計器の搭 載は不可能であるため, 簡易式の安価な AIS 等を搭載し, 他船の情報を有効に提供することが早急に必要であると 思われる．これらの改善により，今後高度な実用化レベ ルのシステムの完成が，十分期待できる.

\section{参考文献}

1) 海上保安庁： http://www.mlit.go.jp/jtsb/kai/bunseki/bu nsekikohosiryo/no3_pleasure/pureshort.htm, 2015.

2) 塩谷茂明, 牧野秀成, 永吉優也, 柳馨竹, 嶋田陽一 : 沿岸航海の安全のための航海シミュレーションに関 する研究，土木学会論文集 B3 (海洋開発)，Vo.67, No.2,pp.I_838-I_843, 2011.

3）小瀬邦治，長谷川和彦 : 操船シミュレータとその安 全性評価への利用, 日本造船学会運動性能研究委員 会・第 2 回シンポジウム, pp.89-114, 1985.

4) 柳 馨竹，塩谷 茂明，牧野 秀成 : 沿岸航海の安全の ための航海シミュレーションにおける気象・海象に 関する航海情報の提示の研究，土木学会論文集 B3(海洋開発), Vo.68, No.2, pp.I_1187-I_1192, 2012.

5) 塩谷 茂明, 牧野 秀成, 柳 馨竹: 沿岸航海の安全支 援のためのカーナビの利用と航海情報に関する研究, 海洋開発論文集，土木学会論文集 B3(海洋開発), Vo.68, No.2, pp.I_1193-I_1198, 2012.

6) 塩谷 茂明，柳 馨竹，笹 健览：小型船舶の夜間 入出港時における海難方止用の航海支援システム構 築の基礎研究，第 50 回土木計画学研究発表会 (秋大 会）講演論文集，pp.1-7，CD-ROM，2014.

\section{STUDY ON VALUATION FOR NAVIGATIONAL SIMULATION AND SEA NAVIGATION SYSTEM}

\section{Xinzhu RYU, Shigeaki SHIOTANI and Kenji SASA}

Authors constructed the basis of navigational system and sea navigation for safety of a sailing small boat in coastal sea areas in a bay and a port. Therefore, in order to evaluate the simulation and navigation systems authors have developed, a questionnaire is conducted toward the third grade students of navigational course of Faculty of Maritime Science, Kobe University. In the questionnaire, the navigation, bathymetric and meteorology information of the navigational simulation and the sea navigation supplied by the simulation and real-time navigational system are evaluated by the presentation of the images recorded during the experiments. It is confirmed that the navigational simulation and the sea navigation are very effective. Also, many effective comments to two system were obtained. 